\title{
The marginalization of astrology among Dutch astronomers in the first half of the I7th century
}

\section{Rienk Vermij}

University of Oklahoma, USA

\begin{abstract}
In the first half of the 17th century, Dutch astronomers rapidly abandoned the practice of astrology. By the second half of the century, no trace of it was left in Dutch academic discourse. This abandonment, in its early stages, does not appear as the result of criticism or skepticism, although such skepticism was certainly known in the Dutch Republic and leading humanist scholars referred to Pico's arguments against astrological predictions. The astronomers, however, did not really refute astrology, but simply stopped paying attention to it, as other questions (in particular the constitution of the universe) became the focus of their scholarship. The underlying physical view of the world, with its idea of celestial influences, remained in vigor much longer. Even convinced anti-Aristotelians, in explaining the world, tried to account for the effects of the oppositions and conjunctions of planets, and similar elements. It is only with Descartes that the by now widespread skepticism about predictions found expression in a philosophy that denied celestial influence.
\end{abstract}

\section{Keywords}

Astrology, celestial influence, astronomy, natural philosophy, humanism

In 1659, the famous astronomer and mathematician Christiaan Huygens was asked to cast a horoscope for one of the princesses of Orange. The princes of Orange were his family's main patrons and Huygens was therefore hardly in a position to turn down the

\section{Corresponding author:}

Rienk Vermij, Department of the History of Science, The University of Oklahoma, 60I Elm Avenue, Room 625, Norman, OK 73019-3106, USA.

Email: rienk.vermij@ou.edu 
request. However, he had to admit that not only he did not believe in astrology, but even that he had never occupied himself with it. He knew nothing better to do than to pass on the request to his friend Ismael Boulliau. ${ }^{1}$

It is perhaps not very surprising that Huygens felt skeptical about astrology, ${ }^{2}$ but it is remarkable that he was ignorant about it. After all, Huygens had had a full training in mathematical and astronomical theories and techniques. He had been taught at The Hague by Stampioen, at the University of Leiden by Frans van Schooten Jr, and later at Breda he had been familiar with John Pell. Yet in spite of all this training, he was not capable of casting a simple horoscope. Apparently, by the middle of the 17th century it was possible to be a first-rate astronomer and mathematician and not have the haziest idea about astrology.

Less than 50 years earlier, astrological techniques were a self-evident part of mathematical training at Dutch universities. When in 1607 Isaac Beeckman asked the professor of mathematics at Leiden, Rudolf Snellius, for advice on the study of mathematics, Snellius gave him a list of books to study that included not only works of "Astronomia" ("Ptolomaeus, Copernicus"), but also "Astrologia" ("Ptolomaeus, Hermes"). ${ }^{3}$ Snellius praised the history and dignity of astrology in the preface to his commentary on Cornelius Valerius's book on spherics. He refuted the "Pythagorean" idea that astrology was a part of mathematics: "But astrology is a part of physics, for it teaches the natures of the stars; and it is not just a part, but the primary and highest part." 4 The first professor of mathematics at the University of Franeker, Adriaan Metius, in 1598 published an astronomical textbook wherein he devoted much space to the discussion of astrological techniques. Chapter 11 of book 2 is devoted to establishing the celestial houses. In 1624, in a new version of the book, the astrological part was even expanded upon to include a discussion of the aspects. ${ }^{5}$ This is in line with our present understanding of 17 th-century astronomy.

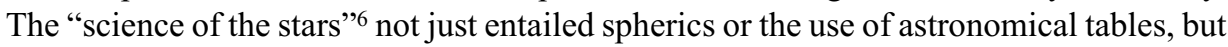
also the art of houses, aspects, etc., which have no significance outside an astrological context.

However, by the time Huygens was growing up, this situation in the Dutch Republic had changed. Students of mathematics no longer were supposed to master astrological techniques, or rather, the subject was completely neglected. It may be significant that Huygens eventually found his astrologer not in the Netherlands, but in France. As will be shown in this article, the generation of Dutch astronomers that succeeded Metius and Rudolf Snellius no longer were interested in astrology. It is not that they wrote extensive refutations; they simply abandoned it. This was not because of lack of demand. Almanacs with prognostications remained popular throughout the 17 th century. ${ }^{7}$ However, in the later period astronomers refused to cater to this demand. Astrological practice in the 18th or 19th century was the work of quacks and soothsayers, not of respected scholars. It lost its connection to ancient astrological theory and had little in common with the learned art of medieval or early modern times. ${ }^{8}$

This marginalization of astrology was probably more abrupt and earlier in the Dutch Republic than in most other places, but it was of course a manifestation of a widespread phenomenon. All over Europe, mostly during the 17th century but at an uneven pace, astrology disappeared from the scientific discourse. This was certainly a very incisive and fundamental development in western intellectual history. Some modern historians 
resist the talk of a "demise" of astrology, as it smacks too much after a traditional positivist narrative, whereby astrology is overcome by the triumph of modern science, and prefer to speak of transformations in a continuing history. One need not object to this point, as long as it is clear that this "transformation" implied a complete loss of credibility in academic and scientific circles.

The demise of astrology in the early modern period so far has drawn remarkably little attention from historians. ${ }^{9}$ Histories of what is traditionally called the scientific revolution focus on new discoveries and insights and seem to take the disappearance of old attitudes for granted. ${ }^{10}$ Although the history of astrology has become a prominent field of research in recent years, researchers have been mostly concerned with demonstrating how important astrology really was in early thought. If they have paid attention to its eventual downfall, then it is largely by focusing on contemporary criticisms and attacks. ${ }^{11}$ However, the question is not how astrology was refuted (which still presupposes some level of interest), but how it came to be ignored. One problem may well be that a topic like astrology's demise does not seem to fit in very well with the current paradigm in the history of science. Modern historians tend to describe the historical development in terms of knowledge that is locally produced and circulates between specific contexts. This more or less subsumes that relevant knowledge is specific and so to speak tangible. It is harder to describe the obliteration of current practices in these terms, especially when this is a general development. For this aim, it would be more fruitful to see the world of knowledge as an integrated system rather than as a collection of localities.

Obviously, I cannot treat the whole system of learning here. I will confine myself to a specific context, the Dutch Republic. As explained above, in the Dutch Republic the discrediting of astrology appears to have been rather swift and clear-cut. Moreover, its limited size allows us to give a pretty comprehensive overview. So, I hope to be able to identify some of the elements, both local and general, that contributed to the downfall of astrology. The following article will not just rehearse the various stances for and against astrology, but also evaluate the changes in self-definition and in the scientific and scholarly ideals of the Dutch astronomers. This hopefully will help us to understand how astrology was separated from the wider academic culture of the period. ${ }^{12}$

\section{Some preliminaries}

Astrology had existed for thousands of years and survived the Hellenistic, Islamic, and medieval European civilizations. It never had an undisputed status and found vehement detractors as well as avid supporters, but it always managed to accommodate itself to the dominant culture. While evidently this protean character makes its rapid downfall in the 17 th century even more enigmatic, it also makes it hard to define what exactly we are talking about. Roughly speaking, astrology is the art of attributing meaning to the constellation of the heavens, but for practical reasons, it will be easier to identify astrology by its formal elements. The heavens were "read" by means of certain elements that astrologers found or constructed in the heavens for this specific purpose, such as houses, aspects, etc. The core of astrology consisted in applying these tools to specific (but not necessarily individual) cases. This could result in elaborate prognostications, but also in 
simple commonplaces, as the claims that epidemics or earthquakes were connected to certain positions of Mars or Saturn.

In those latter cases, astrological understanding gets very close to a physical explanation and, indeed, there were obvious connections. Looking at it from a physicist's point of view, astrology implied a worldview wherein the heavens in one way or other influenced things on Earth. ${ }^{13}$ However, it should be emphasized that astrology could do very well without the physicist's perspective. Medieval and Renaissance scholars indeed often presented astrology as a part of natural science, but it can be argued that this was mainly a move to make it religiously acceptable. It is not a priori clear that astrological practices or beliefs could not exist without such support, nor is it evident that the acceptance of certain physical principles inevitably would entail the application, or more than a limited application, of astrological techniques to understand the world. In other words, the connection between a physical worldview - any physical worldview - and astrology appears actually quite tenuous.

The point is relevant here, for some historians have explained the downfall of astrology by the demise of the underlying physical worldview. ${ }^{14}$ It is indeed hard to belief that there would be no connection at all. Indisputably, as far as astrology understood itself as part of natural philosophy, the rise of a new mechanistic worldview in the 17th century certainly presented problems. On the other hand, the "demise" of astrology can be understood as a rupture of these links between astrology and natural philosophy, at the very moment that physical thinking became all-dominant. If we want to understand the downfall of astrology, the theory of celestial influence and its role in natural philosophy should be separated from actual astrological practice, however much the boundary between the two was blurred.

However, this should not induce us to jump to the other extreme by stating that astrology was really a part of magic or the expression of a magical worldview. It is definitely true that many elements in astrology came originally from the magico-religious sphere, but the same can be said of much of early modern philosophy. The interesting thing about early modern astrology is that it was an accepted (although not unproblematic) part of scholarly learning and was well integrated with current natural philosophical ideas. As it is exactly our task to understand how astrology came to lose that "scientific" status, we have to take the philosophical pretentions quite seriously to begin with.

\section{Some context}

Professors such as Metius or Rudolf Snellius, discussed above, had had their training largely abroad and represented views that were common among European astronomers. On the other hand, the demise of astrology as it took shape in the 17th century seems to have been a local phenomenon and therefore probably the result of local circumstances. Something therefore needs to be said about the specific context we are dealing with.

The Dutch Republic emerged in the late 16th century as a result of the revolt of the inhabitants against their Hapsburg overlord..$^{15}$ The gaining of political independence went hand in hand with an astounding economic and commercial expansion. Dutch political and social life came to be heavily dominated by a nascent merchant aristocracy. It has been argued that the reliance upon commerce created a more factual approach to 
knowledge. Allegorical and symbolical interpretations of the world gave way to exact, "objective" descriptions of concrete things, with an eye for their use and value. ${ }^{16}$ This is certainly an element to keep in mind. Dutch mathematical practitioners did not really need astrology to make themselves socially useful. They first of all catered for the needs of Dutch maritime expansion by producing instruments, maps, and tables for sailors and luxury globes and atlases for rich merchants. Still, one should not exaggerate the break with traditional forms of knowledge. In this highly urbanized and well-educated country, learning was much in demand and there was much openness to outside models. Foreign courts set the tune in fashion and culture, and Renaissance culture flowered among the city aristocracies. Although the country was a republic, the nobility still had a position of note and the court of the stadholder, although certainly not on a par to the princely courts of other countries, was not so insignificant as it used to be assumed. ${ }^{17}$

The Dutch Reformed Church was no state Church, but it was quite influential. Its attitude toward astrology was in line with traditional Christian ideas, although maybe slightly more hostile. The theologians could not really object against the idea that the heavens influenced the generation and corruption of things on Earth in a physical way as long as this did not constrain human will, but they were critical about the possibility of predictions. Gisbertus Voetius, professor at the University of Utrecht and a leading theologian, rejected all astrological prediction-making. He regarded astrology as pagan superstition and called it a "mataiotechna", a useless art. ${ }^{18}$ Another prominent theologian, Jacob Revius, in November 1647 at Leiden held two disputations on astrology, wherein he likewise, and at great length, refuted the soundness of predictions. Although he admitted that the heavens were a general cause of things on Earth, he felt that it was not possible to predict particular effects. ${ }^{19}$ The hostility towards astrology was not just a theoretical stance. Several instances are known of Church councils reproaching Church members who had read the planets, although learned practitioners were normally left alone..$^{20}$

One should add that, although theologians rejected astrology, they certainly believed in portents. Comets, eclipses, or monsters were nearly universally regarded as signs of the impending doomsday and of God's anger about human sins. However, these were warnings only in a general way, and did not predict any specific event. ${ }^{21}$ This should alert us that as little as we can assume a direct connection between astrology and natural philosophical ideas, so little may we presuppose a link with attitudes towards comets, monsters, or miracles. As we shall see, the distinction between celestial signs and astrological predictions can be found in the work of many astronomers as well.

As the Dutch Republic lacked a princely court, higher learning was not supported by royal patronage, but heavily concentrated at the newly founded universities. These universities were secular institutions, not subject to Church control. Their role in the formation of a new astronomical identity was crucial. The main center of learning was the University of Leiden, founded in 1575 and liberally funded by Holland's commercial wealth. The university governors from the start initiated an ambitious program to turn it into an important seat of learning. In particular, they promoted the new humanist scholarship and philological methods of their time.

Under the influence of this program, astronomers came to see their discipline in a new light. Practitioners such as Metius or Rudolf Snellius had drawn part of their credit from 
their expertise in astrology and could therefore ill afford to look down on astrology as a science. Their successors saw themselves as students and restorers of ancient knowledge, rather than as practitioners of an art.

In principle, this left open the possibility that they would work at bringing astrology back to its (presumed) pristine glory, but in practice this is not what happened. The main concern of the humanist-minded astronomers was recovering the true system of the world and its underlying principles, a topic much in debate since the publication of Copernicus' book in 1543. This program led to a lot of scholarly work. Some people would agree that astrology also was in need of reform, but nobody seems to have taken up the challenge. Efforts were simply directed into another direction. So, if astrology came to be neglected, it is not so much because new arguments were forwarded, but rather because the study of astronomy was defined in a new way.

\section{Leiden philologists and astrology}

Humanist scholarship at Leiden was most of all represented by the classical philologists Justus Lipsius and Joseph Scaliger. In particular Scaliger, who came to Leiden in 1593 and died there in 1609, is important to our topic. Besides being one of the main philologists of his time, he also had an active interest in mathematics and astronomy. He is known as founder of the science of technical chronology. Chronology was for Scaliger a study in its own right, not dependent upon religious or other considerations. He studied astronomy for the sake of his chronological studies and as a philologist.

To understand the direction astronomical studies at Leiden would take, it is relevant to point out that Scaliger also looked into astrology. Being not a practicing astronomer, he could afford to be critical. His ideas in this respect have been studied by Grafton. In 1579, many years before he came to Leiden, Scaliger published an edition of the ancient astrological poem of Manilius. In his commentary, he developed a new interpretation of the history of astronomy and astrology. Whereas the established view held that these sciences had existed in their fullness in the earliest times and been handed down, probably defectively, by the Babylonians and Egyptians to the Greeks, Scaliger now argued that astronomy had been perfected only gradually. It had been fairly undeveloped in ancient Egypt and the Near East, and became a systematic science only in the hands of the Greeks. The art of making astrological predictions too had only been turned into a fullfledged system in the Greek period. Ptolemy often contradicted the astrological ideas of his Near Eastern predecessors, Scaliger felt. He valued Manilius' text mainly because it offered a glimpse of the earlier, imperfect state of knowledge, or even of the earlier superstitions. Scaliger thus refuted the common idea that astrology was based on venerable, age-old knowledge. ${ }^{22}$ As Grafton has remarked, in many of his arguments, even in the details, Scaliger had been preceded by Pico della Mirandola in his famous disputations against astrology.

These coincidences suggest that Scaliger may well have seen himself as carrying on one part of Pico's campaign for a reformed astrology, one that would abandon the arbitrary inventions of the ancients and concentrate on the general effects of the heavens, using the most sophisticated mathematical techniques in order to measure them precisely. ${ }^{23}$ 
Whatever Scaliger's relation to Pico, it is clear that he brought to Leiden a powerful critique of astrology. Some years after Scaliger came to Leiden, in 1599, he published a new edition of Manilius. ${ }^{24}$ It was preceded by a "forword on the ancient astrology of the Greeks", wherein he explicitly referred to Pico's disputations:

We are not the ones to believe that the stars and the brilliant celestial bodies are idle. But we utterly deny that their effects are limited by these ridiculous devices and arbitrary divisions. Later practitioners have made so many changes in this art, that when compared with the methods of earlier ones it cannot seem to be the same art. Indeed, in many respects it is contrary. (...) But to refute all this would take much time and many books. Since Count Pico della Mirandola and others have done this, it will suffice that they have pressed a strong attack home on the citadel...25

Scaliger's arguments did not go unheeded at Leiden. The famous scholar Gerardus Johannes Vossius graduated here in 1598. He was neither an astronomer nor a mathematician, but he came to speak of astrology in his great work on idolatry, De theologia gentili. Among the various subjects, he discussed the opinion that fate was determined by the stars. In his view, this opinion rested "partly on true and certain reasons; partly on uncertain ones and very dubious guesswork; and partly on reasons that are wrong, absurd and impious." Vossius unsurprisingly rejected the view that our will is determined by the stars, but he was also critical about the view that the stars influence our bodies and the material world and thereby incline, but do not compel us. Vossius did not dispute that the celestial bodies influence the terrestrial world, but he would not admit

...that the astrologers can read in that celestial book how every soul by nature is inclined. Then the influence of all things has to depend on it as well. And that book is so subtly written, that apart from the One who wrote it, I am not saying that nobody can understand it simply and fully (because that has no place in vulgar arts and sciences), but that even those who are kept for the most understanding in this art only captivate a tiny part. And even that particle is completely conjectural. That this is so, can be proven by many arguments.

As Vossius pointed out, even if the Chaldeans have records of observations, it will take 49,000 years before a certain configuration of the heavens will be repeated. In other words, although Vossius did not doubt celestial influences, he did not believe in the possibility of predictions. The influence of Pico, or Scaliger, in all this appears clear. ${ }^{26}$

After Scaliger's death, his chair in 1632 went to another famous philologist, Claude Saumaise, or Salmasius. Salmasius published in 1648 a thousand-page volume wherein he attacked ancient astrology and number mysticism. In his refutation, like Scaliger he too used mainly philological arguments, besides religious ones. ${ }^{27}$ Skepticism concerning astrological predictions thus appeared a constant factor at Leiden. I am not aware of any Leiden humanists who upheld astrology in some way. ${ }^{28}$

Scaliger's was not the only influence at work. The humanist program was also active in other fields, most notably medicine. Medicine of course was one of the main fields where astrological lore was deemed relevant. Traditionally, many physicians were active astrologers, although others tended to reject it. 
Maybe the most important among the first professors of medicine at Leiden was Johannes Heurnius. He had been trained in Louvain (where he boarded with the mathematician Gemma Frisius), Paris, and Padua. He became a professor at Leiden in 1581 and kept the post until his death in 1601. His medical writings are products of humanist erudition, wherein he showed himself an admirer of Hippocrates and Galen. He wanted to teach their theories in a "pure" form, without the later accretions of Arabic or medieval physicians. As the works of the Hippocratics and Galen do not refer to astrological medicine, it is may be not strange that Heurnius' works are largely devoid of astrological theory.

In his book Praxis medicinae (first edition 1587), Heurnius included a long "astrological demonstration" that surgeons should not decide the moment for blood-letting with reference to the phases of the moon. It is a remarkable piece of rhetoric. Firstly, Heurnius stated that he did not reject celestial influences as such:

I am not the one who wants to rob the stars and the heavens of that divine power, by which things flower here on earth; but I regret that careless men abuse these vital forces by ascribing everything to them in too confused a manner, to the detriment and destruction of the human kind.

Heurnius then set out emphasizing the power of the heavens and their influence on Earth. However, he is careful to attribute this force to the sun only. ${ }^{29} \mathrm{In}$ his Institutiones medicinae as well, Heurnius speaks about this power of the sun, which he identifies with the Stoic pneuma and Plato's world soul. ${ }^{30}$ Unlike the skeptical stance, which goes back to Pico, Heurnius' criticism of astrology appears to have its foundation in a clear view of natural philosophical principles.

There is still a very cursory remark on astrology in Heurnius' work on fevers (first edition 1595), where he speaks of various signs of future or present pestilences. Obscuration of the sun, comets, and the like indicated that the air had been poisoned. "The heavens too give their signs, as when Saturnus, Jupiter, and Mars come together in Scorpio. Because from this aspect of the stars, noxious vapors are generated in the bowels of the Earth, if you believe the astrologers [si fides Astrologis]." ${ }^{\prime 1}$ This does not sound very convinced.

It deserves notice that 20 years earlier, Heurnius had appeared more certain. In 1577, he wrote a vernacular treatise on the comet of that year, wherein he referred to astrological theories. In a conventional way, he explained that the comet had been generated by Mars, the lord of the preceding conjunction, whereas Mercury and Saturn also were lords of the planet. Less conventionally, he also maintained that the comet had been generated by a degeneration of the astral element, occasioned by two preceding eclipses. Referring to Ptolemy's Centiloquium, he interpreted the comet as a sign of future disasters and the upcoming Last Judgment. ${ }^{32}$ One should keep in mind that the 1577 treatise was not a learned work, but a popular pamphlet; the subject is a comet, which was generally regarded as ominous.

So, it appears that alongside the astrological skepticism of Scaliger and others, there was a medical humanism that did not altogether deny the influence of the heavens, but promoted a view of nature wherein the position of stars was of little relevance. Further 
investigation into this medical humanism is needed, but it would seem that Heurnius' approach had quite some influence. In the Dutch Republic, astrological medicine never got a foothold in the medical faculties and astrology was almost completely absent from learned medicine. ${ }^{33}$

\section{The impact of humanism on astronomy}

Astronomy as it was taught at Leiden came to feel strongly the impact of the humanist program, and in particular that of Scaliger. The leading Dutch academic astronomers of the next generation, Willebrord Snellius and Nicolaus Mulerius, were students and admirers of Scaliger and regarded their task mainly as a restoration of ancient knowledge. Other prominent astronomers such as Simon Stevin, Philips Lansbergen and Willem Jansz. Blaeu, although no philologists themselves, kept contacts with the Leiden humanists and were heavily inspired by them. ${ }^{34}$

Under the influence of this program, astronomy changed its character. Whereas traditionally, the discipline had been mostly about the art of astronomical (or astrological) calculations, without bothering much about the physical truth of the models used, the Leiden astronomers were committed to identifying the real constitution of the universe and discovering its order and harmony. The work of Copernicus was of particular importance in this. Whereas traditional astronomers such as Metius simply made no mention of the Copernican question, at Leiden it became a major concern. The issue must have dominated astronomical thinking at Leiden at least since the 1590s, although most works dealing with it were published in the first decades of the 17 th century, rather late in the career of the respective authors. Mulerius wrote in 1616 that the question of the motion of the Earth had been vexing him for 30 years. Lansbergen by 1588 was working on a program of systematic astronomical observations with the goal of finding the true system of the world. Stevin admitted that Gilbert's book on the magnet of 1600 gave him the clue that he had been seeking for a long time. Not all of these people were Copernicans, but whether they accepted the motion of Earth or not, all of them saw it as a major question, and all of them accepted at least some elements of Copernicus' world system, which fitted into their ideal of an ordered, harmonious universe.

With the order and constitution of the universe coming to the forefront, other elements, most notably astrology, receded into the background. In some cases, religious sensibilities may have played a part as well: Mulerius was a strict Calvinist and Lansbergen was a protestant minister. Stevin, however, appears to have been religiously indifferent, and Blaeu, originally a Mennonite, might rather be qualified as a libertine.

The most interesting astronomer for our purpose is Nicolaus Mulerius. He is particularly interesting because he presents two different sides. On the one hand, he was a Leiden-trained scholar, an admirer of Scaliger who published chronological studies himself. He pursued a scholarly career that in the end brought him a professorship in medicine and astronomy. On the other hand, he wrote a popular annual almanac, traditionally an astrologer's job.

As a scholarly author, Mulerius appears to have completely ignored astrology. Having become professor at Groningen at a rather advanced age, he wrote a textbook on astronomy. Traditionally, such a work would contain, among other things, the basic techniques 
of casting horoscopes. As we saw, the textbooks of his colleague at Franeker, Adriaan Metius, in their various editions devoted ample space to the subject. However, in Mulerius' textbook the topic is not dealt with at all. Dealing with the solar year, he started by extolling the virtue of the sun as the remote cause of life (not unlike Heurnius - mind that Mulerius was a physician himself), but he was silent about the other celestial bodies. He mentioned the revolutions of the planets: "but in political use, time is measured only according to the solar and lunar years, ignoring the years of the other planets. Therefore, I will deal mainly with these [sun and moon] in this introduction." 35 This is just about calendars; astrology is not even mentioned to refute it.

There are two instances where Mulerius touches upon the possible influence of the heavens on the terrestrial world. The first concerns the influence of the stars on the weather. Stars becoming visible in the course of the year were traditionally regarded as signs, or alternatively as causes, of the changing seasons. As Mulerius explained, he had, imitating the ancients, in his tables given the times of the rising and setting of stars, adapted to his time-period and location, but

I omitted the state of the air and the station of the winds, which in our northern regions are very uncertain and what will happen is very dubious. For we do not know to the regiment of what star the brothers of Aeolus are subject [there follows an enumeration of the names of the winds], when the star excites them and when it tempers their ire. God has wanted these things to remain mysteries. ${ }^{36}$

This seems to express a deep-seated skepticism about the state of the astrological art, without any hope of future redemption.

The other case concerns the influence of the moon on the tides. This influence, however, is tacitly assumed rather than stated: the chapter on the tides, the very last chapter of the book, is part of the section on the moon. Mulerius does give exact predictions in the form of tables of the times of low and high water for different places on the Dutch coast. These tables were based upon the theory of the moon, of course (the relation between the phases of the moon and the tides was well established at this time), but he did not elaborate on the moon's activity.

Mulerius omitted astrology from his learned astronomical work, but of course he had been fully trained in astrology's techniques and was certainly able to cast a horoscope if called upon. It should therefore not amaze us that he calculated a yearly almanac. It is interesting, however, how he fulfilled this job. The oldest almanac by him that has been preserved is from 1604. The booklet starts with an elaborate praise of astronomy. Astronomy studies the most splendid and most beautiful of creatures. Therefore, it is far from useless. As "a pagan philosopher" said, man is born to contemplate the heavens. At the same time, Mulerius warns against abusing this splendid art: "One would wish that there were among Christians presently no Chaldaeos and Astrologos, that is, abusers of this art." Unfortunately, due to lack of space (he claimed) he abstained from further explaining the use and abuse of astronomy. ${ }^{37}$

The almanac itself consists of tables of the position of the three superior planets at the beginning of each month. (The position of Venus and Mercury is given only for March.) As Mulerius explained further on, knowing their aspects with the sun and moon is "very 
convenient for doctors and surgeons." ${ }^{38}$ The booklet further contains a small chronicle, chronological remarks, predictions of two solar eclipses (invisible in the Netherlands), a blood-letting figure, and further astronomical tables and tables of high and low water. Remarkably, unlike what is common in almanacs of this kind, a prognostication is lacking. Astrology for medical purposes is taken for granted, but there are no predictions based on astrological theory.

The one other almanac by Mulerius that has been preserved is the one for 1608 . Interestingly, the one surviving copy of this almanac is interspersed with blank leaves, carrying some annotations and in one case a horoscope in Mulerius' own hand..$^{39}$ Indeed, if Mulerius did not mention astrology in his work, it was not because he was ignorant of the art. The almanac includes a "Practica", which does include astrological information. Mulerius gives the position of the heavens, that is, the location of the various planets in their houses, at the moment of the vernal equinox. (Actually, this is what the manuscript horoscope shows.) He describes the conjunctions of the planets as a kind of theater play wherein the planets confer with each other or spy upon each other: "This is said following the astrological art, so as it will happen above in the starry heaven. Time will make clear whether such will not be imitated here on earth." This is a reference to the peace talks that were going on between Spain and the Dutch Republic: the conferences between the planets were shown as parallels to the talks between diplomats. This is no serious astrological interpretation, but rather a parody.

The Practica also contained a section on the comet that had appeared in 1607. Mulerius expressly related the appearance of the comet to the new star of 1604: the comet

...had its origin about 90 degrees, that is a quadrature aspect, from the place where three years ago stood the big new star, and than walked to that place and has disappeared there. Haec non accidunt fortuito. There is a special mystery hidden here.

According to Mulerius, great things were going to happen. If the Dutch repent their sins, he claims, we may be spared the punishment and even attain the peace which is so greatly needed. ${ }^{40}$ Mulerius wrote on comets not just in his almanacs, but he also wrote a pamphlet on the comet of 1618, which he interpreted as a divine warning. In this pamphlet, he subscribed to the general view "that nothing is produced from the elements without assistance of the celestial influences and forces." The comet's effects might well be reinforced by those of the two novae of some years earlier. However, Mulerius abstained from giving any specific predictions. ${ }^{41}$

In sum, Mulerius ignored astrology in his learned works and was reluctant to include it in his almanacs. Salman, who made a thorough investigation of Dutch almanacs, found that in his almanacs the astrological element is definitely muted compared to other almanacs: "Nicolaus Mulerius did make prognostications, but foremost occasioned by comets. The practicae which were included in the first half of the century, in spite of their name, only contained astronomical observations, without any conclusions." A similar attitude can be discerned in the continuators of Mulerius' almanacs, first his son Pieter Mulerius and later Johannes Borgesius, both of whom also were professors of mathematics at Groningen. As Salman states: "As long as the Groningen almanacs were taken care 
of by the professors, they remained largely free from predictions. (...) This changed in the 1670s, when surveyors and engineers took over." 42

The other dominant Leiden-trained mathematical scholar was Willebrord Snellius. He was a pupil of Scaliger and in his work very much tried to continue the classical tradition. His work in mathematics took its departure in a study of the original Greek sources and his scholarly reputation was as much due to his philological as to his mathematical skills. In the question of the world system, he remained largely uncommitted, but it certainly had his attention. He wrote on such wide-ranging subjects as geometry, geodesy, navigation, and sunspots, but astrology is almost completely absent from his work. ${ }^{43}$ He only referred to it in his treatise on the comet of 1618 . Snellius definitely felt that comets did have some predictive meaning, but he stated that he attached no great value to Egyptian, Chaldean, or Greek thoughts on the matter. Nor was he impressed by common astrological methods to determine the meaning of comets. If astrology was an art, he stated, it should be based on experience, investigation, sense perception, and induction. Without those, it would just result in old wives' tales. So far, the astrological art had been badly neglected. However, although astrological practice needed very thorough reform, Snellius did not express doubt that in the end it could be made to work. Moreover, his skepticism about present astrological theory did not deter Snellius from falling back to common astrological notions when describing the effect of the comet. As he explained, the comet had a clearly "Saturnine" character, due to the fact that when it came into being, Saturn had infected it with its adverse rays. ${ }^{44}$

Other mathematicians could not lay claim to the status of classical scholars, but still underwent the influence of Leiden scholarship. Simon Stevin was an engineer in the service of the stadholder Maurits of Nassau. For his patron, he wrote Wisconstige gedachtenissen ("Mathematical memoirs"), in five volumes, which contained an important part on astronomical theory. One might expect that, given the courtly context, astrology would get some attention here. This, however, is not the case. It is all about the motion of the planets and the true system of the world (Stevin defended the Copernican system). Stevin's only reference to astrology is in the part of the "Mathematical Memoirs" on geography, where he discussed his project of restoring the knowledge of the "age of the sages", a supposed period of pristine knowledge, well before classical antiquity. Stevin felt that the existence of such an age was attested by some remnants of knowledge that must have been preserved from that period. Among these, Stevin mentioned astronomy ("kennis des hemelloops"), algebra, geometry, knowledge about the atmosphere, alchemy, and magic ("Gheesthandel"). ${ }^{45}$ Notice that astrology is absent here. In order to accomplish the restoration of knowledge, first of all many observations had to be made by many people. Among the fields that should be advanced in this way, Stevin did mention judicial astrology - "experiences of interpretations of the stars, or predictions by the stars", along with astronomy, the tides, physical geography, alchemy, and medicine (in particular anatomy and vegetable and chemical medicaments). ${ }^{46}$ This seems to indicate that Stevin did not think highly of the existing astrological theories of his time, but that he thought at least some forms of astrological predictions feasible in principle. The problem was to find empirical evidence. In this respect, his stance is comparable to that of Snellius (who translated his book into Latin). 
Probably the most active and important Dutch astronomer of the first half of the 17th century was Philips Lansbergen, a Calvinist minister. He published widely both on the theoretical and practical aspects of astronomy (e.g. instruments), but he never bothered to explain astrological theory or discuss predictions. His main commitment was in establishing true astronomical theories, based on the true (heliocentric) system of the world. In this way, he hoped to re-establish the ancient wisdom that God in the past had granted to the Israelites. Although astrology had a marginal place in Lansbergen's astronomy, he was not a principled opponent. He possessed the necessary skills to cast horoscopes and, like Mulerius, he might occasionally use these. So, in 1595 he was asked by a friend (and fellow minister) to cast the horoscope for his newborn child. Lansbergen complied, but without great enthusiasm, it seems, and he emphasized that he was limiting himself strictly to health and diseases, as all other predictions were uncertain. ${ }^{47}$

On the other hand, Lansbergen did incorporate some elements from astrology in his ideas on the constitution of the universe. He did so in a book written for a larger public, his vernacular "Considerations on the annual and diurnal motions of the earth". Herein, he defended a neo-Platonist view of the world. Growth and generation in the world had their origin in the force impressed from the heavens, not just from the stars, but ultimately from the empyrean, the throne of God. ${ }^{48}$ The world was built in an ordered and harmonious way. Lansbergen maintained that each planet had specific qualities, which (as it turns out) corresponded with those traditionally assigned to them in astrological systems. So, the moon was watery, Mars hot and dry, etc. Earth was placed in the middle between the other planets, so that it could undergo their influences in the best possible way. Effects of the planets were noted in the weather. When two planets were in opposition, their effects were enhanced. For instance, when hot planets (the sun and Mars) were in opposition, weather on Earth would be hot; when cold planets were in opposition, weather would be cold. ${ }^{49}$

So, although Lansbergen appears reluctant about predictions, he is not questioning the current ideas on celestial influence. Although adapting them to a heliocentric theory, it should be emphasized that he is not trying to correct or reform astrological theory in the light of his ideas on the world system. Rather, he is trying to incorporate commonly accepted ideas into a new physical framework. This uncritical acceptance of traditional astrological notions appears to have been a common attitude. People like Stevin or Snellius indeed did talk about a reform of astrology, but they clearly aimed at empirically testing astrological effects, not at overhauling basic theory or adjusting it to the new world system. However, even this limited goal remained a theoretical stance. The reform of astronomy was a major preoccupation, but nobody in the Dutch Republic, as far as is known, started a program to test or reform astrology.

The only person who did explain some astrological theory in writing was Willem Jansz. Blaeu, and he did so, it would appear, largely for commercial reasons. Blaeu was an accomplished astronomer who had spent some time with Tycho Brahe at Hven, but later settled as a book-seller, publisher, instrument maker, and cartographer at Amsterdam. He built and sold celestial and terrestrial globes and also published a manual on their use. This manual was directed at a non-academic audience and certainly had a wider distribution than the precious globes themselves. Partly, it served for advertising his own instruments, but it also served for propagating the system of Copernicus..$^{50}$ 
The manual describes how globes can be used to solve various problems in astronomy and geography. Examples are given. Some people might want to use them for astrological calculations, and accordingly, there is also a section on this subject. This section of the book is however very short - much shorter than the astrological section in Metius' textbook. Moreover, Blaeu's formulation is very uncommitted: "The astrologers, who deal with the powers and influences of the celestial bodies in the terrestrial things, and feel that from them they can predict future things, divide the heavens in twelve parts, which they call houses." 51 Blaeu explained how by using a globe one can find the 12 celestial houses. As an example, he calculated their position for Holland (52 $50^{\circ}$ N.B.) on $1571 \mathrm{Dec} 9$ st. vet. at $6 \mathrm{pm}$, the place and time of the birth of Adriaen Metius (as he explained), and showed how to draw the latter's horoscope. This example is clearly taken from Metius' own textbook. ${ }^{52}$

To conclude this part of this article, we can assert that astrology was increasingly ignored among learned astronomers in the Dutch Republic. Their astronomical work was legitimized by its incorporation into the world of humanist scholarship - which, accidentally, in the Dutch Republic stood critically against astrological predictions. Moreover, the main topic they came to discuss was the system of the world. Astrology, although not directly repudiated, moved to the margins of astronomical practice. The astronomers of this generation would still be able to cast horoscopes and would readily do so if called upon. Still, they were not really eager to and expressed skepticism about the empirical underpinning of astrology, and hence its claim to scientific status.

It deserves notice that this skepticism did not cover celestial signs. Lansbergen regarded the new star of 1604 as a sign of the impending Last Judgment. ${ }^{53}$ Mulerius too regarded it as a portent, apparently outside the realm of ordinary natural explanations. ${ }^{54}$ Eclipses could be seen as warnings, too. Lansbergen emphasized that eclipses should be regarded not just from their efficient causes, but also from their final causes, which is to warn men to repent of their sins. ${ }^{55}$ In his almanac for 1608 , Mulerius wrote of the impending danger of the three eclipses of that year: "God save us from the harm which this last eclipse will bring..." 56 On the other hand, one of the professed uses of his 1616 textbook was to take away the superstitious fear of eclipses. ${ }^{57}$ Celestial signs were warnings in a general sense and by their own nature did not predict any specific events. Moreover, all astronomers regarded comets as signs of impending evil..$^{58}$

Interestingly, in the case of comets, astrological considerations appear to have been an accepted element in their explanation. They turn up in the work of Heurnius, Mulerius, and Snellius. They did not serve predictions, however, but rather helped determine the nature of the comet. This underlines the important fact that none of the people discussed so far appears to have doubted celestial influences as such. However, these influences were not referred to in order to legitimize predictions about events happening on Earth, but rather used as an element in the physical understanding of things in the heavens - the occurrence of comets, or the constitution of the universe. Well in line with the shifting interests of these astronomers, they were discussed as elements in a physical, rather than an astrological discourse.

\section{Astrology and the debate on a new physics}

The question of the constitution of the universe would dominate the astronomical agenda for the next century. Especially the telescopical discoveries of Galileo made the question 
urgent, but besides, there were the theories of Tycho Brahe, the appearance of new stars, etc. The professors of the middle of the century, foremost of all Martinus Hortensius at Amsterdam, Johannes Phocylides Holwarda at Franeker, and Jacobus Ravensberg at Utrecht, discussed the physical constitution of the universe, but none of them, as far as is known, occupied himself with astrological predictions. Astrological techniques are completely absent from their known works. They often even are decidedly more hostile than Mulerius or Lansbergen, who, although being skeptical, had never actively opposed astrological practice.

Jacobus Ravensberg, a student of Mulerius, in 1642 published an all-encompassing Encyclopedia mathematica. It included a section "Astrologia", which, however, is completely negative in tone. According to Ravensberg, astrological methods are "empty and superstitious". Eclipses do not predict anything. The "great year", a term that was used to denote long-term periodicities in the position of the planets that were thought to determine world history, is nonsense. For the rest, Ravensberg did not publish on astrology. Astronomical disputations defended at Utrecht under his professorship ignored astrological topics. ${ }^{59}$

Johannes Phocylides Holwarda not only was a convinced Copernican, he also was an early advocate of Kepler's theories. He is best known as discoverer of the variability of the star Mira Ceti. In the booklet he published on the star, which he initially regarded as just a new star, he emphatically denied that such new stars have a special meaning. According to him, these are natural phenomena as any other. Holwarda was especially scathing about astrological interpretations of such phenomena, pointing out that all astrological predictions were irreligious. ${ }^{60}$

The case of Hortensius, a student of Lansbergen and the first Dutch professor openly to defend heliocentricity, is the least clear. Descartes at some point reported that he had casted a horoscope, but his words have the character of gossip and look completely unreliable. ${ }^{61}$ In Hortensius' works, astrology is absent. However, he did believe in celestial influence. Against Gassendi, who had argued that the unexpectedly small size of Mercury as revealed by the transit of 1631 denied any influence of this planet on Earth, Hortensius argued: "Perhaps the disposition of the special matter of that planet is such, that under a small bulk lies hidden an enormous force." $\mathrm{He}$ mentioned gunpowder as another example that size did not always correspond to effect. As the effects of the sun and moon on Earth were obvious, Hortensius felt that we could not deny all influence of the other planets. However, although he conceded "general impressions on the elementary world", he rejected any belief in "the effects on particular human actions... which are based on I do not know what vain and frivolous principles." 62

To all intents and purposes, by 1640 astrology as a part of mathematical astronomy was dead and buried. ${ }^{63}$ At the same time, as the case of Hortensius shows, the theory of celestial influence was still alive and kicking. With astronomers becoming ever more involved in the problem of the constitution of the universe, and new phenomena being discovered, physical issues became ever more prominent. The new view of the heavens called for a new physics and for the moment, it was unclear what elements of the old worldview were to be preserved and what not. Understandably, in many case astronomers tried to incorporate common ideas on celestial influence in their new view of the 
world, which thereby gained a new actuality. One might even say that astrology was completely reduced to its physical aspects.

This debate did not remain confined to astronomy. Celestial influence was a physical rather than an astronomical topic. Once the challenge of the new world system had become clear, philosophers were not slow to take the matter to heart. Earlier, philosophers had hardly paid attention to it. At Leiden, the humanist program had had little impact on the teaching of philosophy, which remained a rehearsal of standard knowledge. Professors of philosophy would more or less routinely discuss the issue of celestial influence. A disputation of 1599 on the whole of nature included a discussion on the (favorable or unfavorable) character of the planets, and celestial influences. ${ }^{64}$ A disputation of 1607 stated that the motion of the heavens serves the generation of living beings in the inferior world, but do not have power over the rational soul, or over demons. ${ }^{65}$ Besides, a disputation from 1600 hints at astrology in discussing magic. ${ }^{66}$

The most respected philosophy professor was Franco Burgersdijk, who taught philosophy at Leiden for many years, from 1620 to 1635, and got some international renown, be it largely as a teacher. Burgersdijk was an Aristotelian, but rather eclectic in his approach and aware of the problems posed by Copernicus' theory. In 1627, he gave his views on astrology in a disputation on the heavens. What he offered is mainly a standard scholastic overview. Burgersdijk maintained that the heavens acted upon the terrestrial world, not just by light and motion, but also by occult qualities. The heavens produce inanimate substances, as stones and metals. In the generation of imperfect animals (by spontaneous generation), the heavens play the role of the seed. In the generation of perfect animals, they only dispose the matter, but do not influence the soul. The effect on the human will was only indirect, to wit, as far as the will followed the inclinations of the body. From this, Burgersdijk concluded that one indeed could predict from the stars things like the weather, fertile and infertile years, epidemics, and also the gifts and future behavior of newborn infants, as far as these depended upon the body's temperament. Even so, he seems to have picked up some of the criticism of Pico and Scaliger, as he warned

that the sublunar things undergo the influence of the stars in very different ways. It is therefore very difficult for humans to know the power of the stars so exactly as is necessary for such predictions. Experience also teaches that most of such predictions are vain and false. ${ }^{67}$

In the second quarter of the 17 th century, the issue became of more interest to philosophers. On the one hand there were the innovators - philosophers who wanted to transform natural philosophy, and pondered about the place of celestial influences. On the other hand there were more traditionally minded philosophers who, exactly because the ancient worldview was under attack, might feel urged to defend the ancient positions, including those on astrology. The latter attitude can be found in the work of Albertus Kyper. Originally from Germany, Kyper studied medicine at Leiden and became a professor of philosophy, first at Breda and later, from 1650, at Leiden. ${ }^{68}$ Working at a time that the new mechanical philosophy started its onmarch, he came out as an adversary of the new physics (and of Copernicanism) and wanted physics to be based on the Bible. In his textbook Institutiones physicae, the fourth book was devoted 
to the stars. Herein Kyper included sections on their operations, effects, and occult qualities. The stars had primary and secondary qualities by which they governed the sublunary world: "they produce various tempests according to the diversity of the times and the constitutions, high and low prices of the crops, fecundity or sterility of the animals, their health, they give rise to illnesses, and mutate things in other ways." 69 Apart from qualities such as heat and cold (identical in nature to these qualities in the elements), the stars had occult qualities as well. Their influences were not just felt in the sublunary world, but also in the heavens itself. Astrological prediction-making therefore made perfect sense, "as it relies on the virtues of the stars and the law of their motion, and is confirmed by various experiences." 70

Still, Kyper admitted that predictions remained uncertain, because of the many unknowns in the powers of the stars and the way they combined. Moreover, often the stars worked only indirectly. They only governed over the material world, not over our rational faculties. Then, even with respect to the stars, irregularities [monstra] might occur or things might happen by chance. A good astrologer should keep that in mind, lest he would not fall into impiety. Kyper warned against the various ways to abuse astrology. He posed the question whether astrology is allowed for Christians. His answer: "Yes, if it remains constricted within certain limits. No, if it lowers itself to the impiety and the idolatry of the mages." $" 11$ It would seem that Kyper defended astrological predictions mainly as part of the traditional worldview he wanted to uphold, not because he was enthusiastic about predictions themselves. There are no indications that he ever practiced astrology himself.

An example of a more innovative philosopher is Henricus Renerius, professor of philosophy at Utrecht and a friend of René Descartes. He was the first university professor in the Netherlands publicly to defend Kepler's elliptical orbits, so he clearly had some astronomical interests, although nothing is known about an astronomical background. He strongly rejected occult qualities, and although he did not deny celestial influences, his physical explanation was somewhat novel: "We do not admit the effects or influences of the heavens themselves upon the inferior world. Whatever virtues reach us, or other bodies, from the celestial region, come all from the very stars." 72 This influence was the effect of the stars' light only. Renerius' ideas therewith tended towards a "mechanization" of the idea of astral influence.

Such influence was especially exercised by the light of sun and moon. The other celestial bodies, even in combination, had only a small power on Earth. According to Renerius, the variability in the effects was dependent upon the medium through which the light passed, the various positions of the stars with respect to each other, reflections under different angles, etc. The rays were stronger when the planets were facing the Earth directly. "And we feel that from these differences in directions and reflexions of the light rays depend all differences and mutations of regions, earth and air." 73 That is, Renerius did not question existing general ideas about the effects of the planets, but he explained these in a new way.

The most important Dutch natural philosopher of the first half of the 17th century worked outside university: Isaac Beeckman. He very neatly shows the combination of a thorough rejection of all prediction-making on the one hand, and a fascination with celestial influences for the explanation of the physical world on the other. Beeckman had 
studied at Leiden and later took a degree in medicine at Caen. He had had mathematical training (having had the advice, as we saw in the beginning, of Rudolf Snellius), but was not active as a mathematician or astronomer (although he made some observations). He was rector of a Latin school. He did not publish anything, but noted his ideas in a private diary. He was a pioneer mechanical philosopher who had a strong influence on the young Descartes. His main goal was the rejection of occult qualities, or rather all qualities in an Aristotelian sense. All phenomena in the world had to be explained by "mechanical" causes, that is, by contact of material particles. ${ }^{74}$

As in the case of Renerius, Beeckman's mechanical principles did not deny that the stars have some influence on the terrestrial world. He repeatedly pondered the subject in his notes. In 1616 he pondered how the aspects of planets could influence the terrestrial world. The fact itself did not appear improbable to him. Based on his speculations, he proposed that there should be a fifth aspect, whereby the heavens are divided into five equal parts. The issue occupied him still in 1631, when he entered two elaborate notes on planetary exhalations, which dealt with the questions where the planets' influence originated and how it reached us. ${ }^{75}$ At another instance, he tried to connect critical days in illnesses with the periodicity of the motion of sun and moon. ${ }^{76}$ In all cases, he maintained that the effect of the heavens could be explained by natural, that is, mechanical causes.

On the other hand, Beeckman ridiculed astrological predictions. To his annoyance, he found that in his hometown (Dordrecht) his scientific investigations had given him a reputation of a wizard and an astrologer. So, on 9 February 1628, a rumor spread that he had predicted from a lunar eclipse the loss of three towns in the war with the Spanish. As Beeckman noted in his diary, he had only observed the eclipse through a telescope, together with some guests and other people, "without prognosticating anything, yes, even detesting doing such prognostications. Nor was there any mention of loss or towns." 77 Three years later something similar happened:

1 August 1631 the rumour went through the town that I had read in the stars that the town of Dordrecht would burn on its four corners on Wednesday. Now, as is clear from my writings, nobody is more suspicious about predictions than I am, because of human ignorance. Therefrom you may see how people who seem to know a bit more than the ordinary, get famous and an undeserved reputation. ${ }^{78}$

Although for Beeckman celestial influences were still a legitimate subject of speculation, he adamantly rejected the identity of an astrologer - even though he had studied the subject in his youth.

Being now completely reduced to being an element in physical speculations, astrology would not survive the radical change in natural philosophy that occurred by the middle of the 17 th century. In the 1640 s, Descartes put forward his new mechanical philosophy, which quickly outdid all its rivals for the renewal of natural philosophy. Descartes too rejected occult qualities, or rather, anything qualitative in nature. However, unlike philosophers such as Beeckman or Renerius, he drew from this the conclusion that celestial influences too should be completely abandoned. Even the tides were not explained by some special virtue of the Moon, but by the pressure of the Earth's vortex upon the seas, without any appeal to the character of the moon or any rays. 
As Cartesianism came to dominate the Dutch intellectual scene, little was heard any more of the theory of celestial influences. It is true that Cartesianism had many adversaries as well and that Aristotelianism was not immediately gone. However, such resistance to Cartesianism was mainly motivated by religious considerations. The main stronghold of the anti-Cartesians was the biblicism of Voetius and his allies. These people were deeply suspicious of astrological predictions (even though Voetius, as stated earlier, was adamant that comets announced evil). They might accept celestial influence as an element of the traditional worldview they were committed to uphold, but they were hardly in a position to speculate about it. Among Aristotelian philosophers too, little was heard about the subject any more. ${ }^{79}$

\section{Conclusion}

That the philologists and physicians who set the tone at Leiden were critical of astrology seems to have been more or less accidental. At many other places, humanist scholarship favored astrological learning rather than discredited it. The direct impact of humanist scholarship on the dwindling of astrology seems to have been a local Dutch characteristic. However, the influence of humanist learning was not only direct, by promoting specific theories, but also indirect, by facilitating the redefinition of old disciplines - in this case, astronomy - and by formulating new scientific ideals. This indirect impact appears to have been much more important. It does not seem believable that the humanist scholarship itself was sufficient to marginalize astrological practice. Indeed, criticism of astrology was not dependent upon this form of scholarship; when humanist learning lost appeal, astrology did not return. Leiden humanist learning acted as a catalyst, rather than being a real cause. It may help explain why the abandonment of astrology in the Dutch Republic was so sharp and sudden, but the real causes for the abandonment lay elsewhere.

As the downfall of astrology was a Europe-wide phenomenon, although happening at very unequal pace, the causes for this phenomenon should not be sought in local particularities, but rather in developments of a general nature. The debate on the system of the world and the constitution of the universe was a general characteristic of intellectual life, which in the long run no professor of astronomy or philosophy could ignore. Coming to terms with these new problems and possibilities put new demands on astronomy and philosophy. These disciplines not just had to cope with new questions; they also had to abandon old ones. Indeed, in the Dutch Republic at least, the debates on the world system appear to have been a main reason for the abandonment of astrological practices among astronomers. ${ }^{80}$

How far this holds as a general mechanism remains to be seen. It is certainly striking that whereas at Leiden, astronomers combined a skeptical attitude towards predictions with a deep interest in the constitution of the universe, at Wittenberg rather the opposite was the case: predictions were deemed of the utmost importance, whereas the debates on the world system were largely ignored.$^{81}$ Of course, this inverse relation does not hold universally. There were Copernicans interested in astrology, although it remains to be seen how far their interest concerned mainly the physical aspects (as seems to have been the case with Kepler), rather than the art of making predictions. As for the claim that 
heliocentricism itself was introduced partly to solve problems in astrology, ${ }^{82} \mathrm{I}$ can only say that the case of the Dutch Republic offers no indication for that.

The main conclusion is negative: astrology did not disappear because of the demise of the underlying worldview. Long before the theory of celestial influence was discredited by the new philosophy, astrology already was generally ignored or even repudiated by respectable scholars. If one wants to uphold a relation between the demise of astrology and the changing world picture, it would rather work in the opposite way: Descartes' work offered a legitimization for people not to believe in astrology. One of the reasons that Descartes' mechanical philosophy appealed to so many people was that he offered a philosophical framework in which the many discoveries and insights of the 16th and early 17 th centuries made sense. So, one might well ask whether his work did not become popular in part because people no longer believed in astrological predictions and therefore welcomed a philosophy that radically did away with celestial influences and occult causes.

\section{Acknowledgements}

The author owes gratitude to Darrel Rutkin for his extensive comments and criticisms. Earlier versions were presented at the religious studies reading group at the University of Oklahoma and at a workshop of the Lorentz center (Leiden) on mathematical life in the Dutch Republic. I thank the various participants for their comments, in particular Matteo Valleriani. Eric Jorink and Rob van Gent also gave helpful comments at various stages, as did an unknown referee. I owe gratitude to Margaret Gaida and Henry Zepeda for correcting the English.

\section{Funding}

This article is an offspring of my earlier research on the reception of Copernicanism. Those investigations were supported by the Foundation for Historical Research, which is subsidized by the Netherlands Organization for Scientific Research (NWO).

\section{Notes}

1. Huygens to Boulliau, 1659 Dec. 11. Christiaan Huygens, Oeuvres complètes, II (The Hague 1889) 524. On this episode: Henk. J.M. Nellen, Ismaël Boulliau (1605-1694). Astronome, épistolier, nouvelliste et intermédiare scientifique. Ses rapports avec les milieux du"libertinage érudit" (Amsterdam and Maarssen 1994) 300-303.

2. At a later occasion (Kosmotheoros), Huygens dismissed astrology as "a miserable, often harmful folly." Huygens, Oeuvres complètes, XXI (The Hague 1944) 737.

3. Journal tenu par Isaac Beeckman de 1604 à 1634, C. de Waard ed. (4 vol., The Hague 19391953) IV, 17. Cf. K. van Berkel, Isaac Beeckman (1588-1637) en de mechanisering van het wereldbeeld (Amsterdam 1983) 25.

4. Rudolph Snellius, In sphaeram Cornelii Valerii praelectiones (Frankfurt 1596), preface: "Est autem Astrologia Physicae pars, quia docet naturas astrorum, \& non modum pars, sed prima summaque pars..."

5. Adriaan Metius, Doctrinae sphaericae libri V (Frankfurt 1598) 105-117. Adriaan Metius, De genuino usu utriusque globi tractatus (Franeker 1624) 93. For a bibliography of Metius' works, see D. van Netten, Koopman in kennis. De uitgever Willem Jansz. Blaeu (1571-1638) in de geleerde wereld van zijn tijd (dissertation Groningen 2012) 209-213.

6. See for a discussion of this concept Robert S. Westman, The Copernican question. Prognostication, scepticism and celestial order (Berkeley etc. 2011) 34-40. 
7. Dutch almanacs have been studied thoroughly by Jeroen Salman, Populair drukwerk in de Gouden Eeuw. De almanak als lectuur en handelswaar (Zutphen 1999). See 41-134 on astrology and medical astrology.

8. The most prominent, and notorious, Dutch astrologist of the 18th century was Johan Christoffel Ludeman, see D.J.H. ter Horst, Franciscus Lievens Kersteman. Het leven van een 18e-eeuwschen avonturier (Amsterdam 1937) 104-167. On 19th century "planeetlezeressen" (readers of the planets), see Willem de Blécourt, Het amazonenleger. Irreguliere genezeressen in Nederland 1850-1930 (Amsterdam 1999) 115-117.

9. See for a recent discussion Darrel Rutkin, 'Astrology', in K. Park and L. Daston ed., The Cambridge history of science, III, Early modern science (Cambridge 2006) 540-561. Peter Whitfield, Astrology. A history (London \& New York 2001) 177-187, with on p. 180 a list of earlier suggested explanations, all based in the scientific developments.

10. For instance, H.F. Cohen, How modern science came into the world. Four civilizations, one seventeenth-century breakthrough (Amsterdam 2010) does not deal with the disappearance of astrology.

11. General overviews of the history of astrology have of course paid some attention to the matter: Kocku von Stuckrad, Geschichte der Astrologie von den Anfängen bis zur Gegenwart (München 2007) 264-274. Wolf-Dieter Müller-Jahnke, Astrologisch-magische Theorie und Praxis in der heilkunde der frühen Neuzeit (Stuttgart 1985) 245-259. Stefano Caroti, L'astrologia in Italia. Profezie, oroscopi e segreti celesti, dagli zodiaci romani alla tradizione islamica, dalle corti rinascimentali alle scuole moderne: storia, documenti, personaggi (Rome 1983) 283-288. William Clark, 'Der Untergang der Astrologie in der deutschen Barockzeit', in: Hartmut Lehmann and Anne-Charlott Trepp, Im Zeichen der Krise. Religiosität im Europa des 17. Jahrhunderts (Göttingen 1999) 433-472 offers less than the title promises.

12. The overview is for a large part based on Rienk Vermij, The Calvinist Copernicans. The reception of the new astronomy in the Dutch Republic (Amsterdam 2002). This book, however, does not refer to astrology.

13. J.D. North, 'Medieval concepts of celestial influence: a survey', in: P. Curry ed., Astrology, science and society. Historical essays (Woodbridge and Wolfeboro 1987) 5-17. Idem, 'Celestial influence - the major premise of astrology', in: P. Zambelli ed., Astrologi hallucinati. Stars and the end of the world in Luther's time (Berlin 1986).

14. Keith Thomas, Religion and the decline of magic (New York 1971) 349.

15. For an excellent overview of the history of the Dutch Republic, see Jonathan Israel, The Dutch Republic. Its rise, greatness and fall 1477-1806 (Oxford 1995).

16. Harold J. Cook, Matters of exchange. Commerce, medicine and science in the Dutch Golden Age (New Haven and London 2007). See also Willem Frijhoff, 'The emancipation of the Dutch elites from the magic universe', in: D. Hoak and M. Feingold ed., The world of William and Mary. Anglo-Dutch perspectives on the revolution of 1688-89 (Stanford (Ca.) 1996) 201218, 305-311.

17. Kees Zandvliet, 'Het hof van een dienaar met vorstelijke allure', in: Kees Zandvliet ed., Maurits prins van Oranje (Amsterdam and Zwolle 2000) 36-63.

18. Eric Jorink, Reading the book of nature in the Dutch Golden Age, 1575-1715 (Leiden and Boston 2010) 136-138. J.A. van Ruler, The crisis of causality. Voetius and Descartes on God, nature and change (Leiden 1995) 290.

19. Jacob Revius, De iudiciis astrorum and De iudiciis astrorum altera. The second thesis of the second disputation reads: "Diximus coelum esse causam universalem, quare futuros effectus particulares non nisi universaliter $\&$ indeterminate in eo contineri \& cognosci possunt." These disputations are preserved, as numbers 52 and 53, respectively, in a collection of Revius' disputations, Analectorum theologicorum disputationes (Leiden 1653) (The Hague, Royal 
Library, 229 L 1). They have been discussed by Enny de Bruijn, Eerst de waarheid, dan de vrede. Jacob Revius 1586-1658 (Zoetermeer 2012) 490-494. See also Jorink, Reading the book of nature (ref. 18), 138-139.

20. On the attitude of the Dutch Reformed Church toward astrology, see Jeroen Salman, Populair drukwerk (ref. 7), 53-57. For Church councils reproaching astrologers, see A. Th. van Deursen, Plain lives in a Golden Age. Popular culture, religion and society in seventeenthcentury Holland (Cambridge 1991) 374 footnote 161. See also De Bruijn, Eerst de waarheid (ref. 19), 221-222.

21. On Reformed views on prodigies etc., Van Deursen, Plain lives (ref. 21), 253-254. On views on prodigies, especially comets, generally in the Dutch Republic, Jorink, Reading the book of nature (ref. 18), 109-142.

22. Anthony Grafton, Joseph Scaliger. A study in the history of classical scholarship, I, Textual criticism and exegesis (Oxford 1983) 184-224; see for astrology esp. 208-210, for a summary 212 .

23. Ibid., 220-221.

24. Anthony Grafton, Joseph Scaliger. A study in the history of classical scholarship, II, Historical chronology (Oxford 1993) 437-459.

25. Translated by Grafton, Joseph Scaliger, I (ref. 22), 221. The Latin text is given in an appendix, ibid., 352 .

26. Gerardus Johannes Vossius, De theologia gentili et physiologia christiana, sive de origine ac progressu idololatriae (Amsterdam: Blaeu 1641; repr. New York and London 1976) I, 562-575, quotes on 564, 574. On Vossius, see C.S.M. Rademaker, Life and work of Gerardus Joannes Vossius (1577-1649) (Assen 1981).

27. Jorink, Reading the book of nature (ref. 18), 141-142. Salmasius' book was titled De annis climactericis et antiqua astrologia diatribe.

28. There are some references to astrology in Caspar Barlaeus' Oratio de coeli admirandis (1636), again in a skeptical vein. See Dirk van Miert, Humanism in an age of science. The Amsterdam Athenaeum in the Golden Age, 1632-1704 (Leiden and Boston 2009) 249.

29. Johannes Heurnius, Praxis medicinae nova ratio: qua, libris tribus methodi ad praxin medicam, aditus facillimus aperitur ad omnes morbos curandos. Editio postrema, emendatior (Leiden 1609). This edition is included in Johannes Heurnius, Opera omnia (Leiden 1609), volume I. In this edition, the various treatises are included with their own title page and pagination. I owe gratitude to Saskia Klerk for help in locating the various passages in Heurnius' work.

30. Johannes Heurnius, Institutiones medicinae, editio altera (Leiden 1609) 19. In Heurnius, Opera omnia (Leiden 1609).

31. Johannes Heurnius, De febribus (Leiden 1610), in Opera omnia (Leiden 1609). The book is a part of Heurnius' Praxis medicinae particularis.

32. Tabitta van Nouhuys, The age of two-faced Janus. The comets of 1577 and 1618 and the decline of the Aristotelian world view in the Netherlands (Leiden 1998) 189-200. Jorink, Reading the book of nature (ref. 18), 126.

33. Cook, Matters of exchange (ref. 16), 146: "Dutch university medicine never favored the teaching of medical astrology." See also Salman, Populair drukwerk (ref. 7), 104, footnote 10 .

34. Cf. Vermij, Calvinist Copernicans (ref. 12), 15-99.

35. Nicolaus Mulerius, Institutionum astronomicarum libri II (Groningen 1616) 65.

36. Ibid., 96-97: "omisso aëris statu \& ventorum statione, quae in hisce regionibus Septemtrionalibus valdè sunt incerta, \& fori omninò dubii. Ignoramus enim cujus stellae imperio subjecti sunt AEolij fratres, Auster, Boreas Eutus, Zephyrus, quodnam sidus ipsos excitet, quodnam iras eorum temperet. Deus ista in arcanis esse voluit." 
37. Nicolaus Mulerius, Almanach voor het schrickel-jaer/ nae de geboorte Christi M.VIc. IIII (Groningen 1604). Only copy: Leiden, University library. Salman, Populair drukwerk (ref. 7), 49.

38. Ibid., C iv.

39. Nicolaus Mulerius, Almanach voor 't jaer nae de gheboorte Christi M.DC.VIII (Groeningen 1607). Groningen, University Library, uklu KWA 646. The horoscope is inscribed: "Ingressus Solis in arietem Martij 9-5-16-3'8 a meridio". Subscribed: "Conjunctio Saturni et [Martis]. 3 Mai. Locus novae stellae in 10 domo in [triangle] [Jupiter]." For a reproduction, see Jorink, Reading the book of nature (ref. 18), 137. The other notes concern eclipses, weather, chronology, and some notable personal and public events.

40. Ibid., [C5].

41. Nicolaus Mulerius, Hemelsche trompet Morgenwecker ofte comeet met een langebaert (Groningen 1618), cap. V. Van Nouhuys, The age of two-faced Janus (ref. 32), 537-542. Jorink, Reading the book of nature (ref. 18), 127-129.

42. Salman, Populair drukwerk (ref. 7), 66-67.

43. On Snellius, see Liesbeth de Wreede, Willebrord Snellius (1580-1626). A humanist reshaping the mathematical sciences ( $\mathrm{PhD}$ thesis, Utrecht University, 2007).

44. Tabitta van Nouhuys, The age of two-faced Janus (ref. 33), 531, 534-536. Van Nouhuys sees Snellius' demands on the astrological art as inspired by Ramism. See also Jorink, Reading the book of nature (ref. 18), 129-130.

45. Simon Stevin, Wisconstige gedachtenissen (Leiden 1605-1608) I, Eertclootschrift, 9-15.

46. Ibid., 19: "voort ervaringen der steroirdeelen of voirsegginghen deur sterren"; in a note the Dutch term is explained as "Iudiciariae Astrologiae".

47. Letter to Adriaen van der Mijle, 1595, Leiden, University Library, PAP 2: "Genesin porro filij tui examinare mihi nondum, per occupationes, licuit; (...) Ubi otium fuerit, non patiar ut officium meum desideres. Meminisse tamen eius te velim, quod coram monui, incertissimos esse Astrologorum Aphorismos genethliacos, praeter eos qui de valetudine ac morbis nati: quare de his tantum inquiram."

48. Philips Lansbergen, Bedenckingen op de dagelyckschen, ende iaerlijckschen loop van den aerdt-kloot (second edition, Middelburg 1650) 52, 97-99. The first edition is from 1629. There are no significant textual differences between the various editions, or with the Latin translation.

49. Ibid., 77-79.

50. On Blaeu, see van Netten, Koopman in kennis (ref. 5). On his Copernicanism and the globe manual, cf. Vermij, Calvinist Copernicans (ref. 12), 68-72.

51. Willem Jansz. Blaeu, Institutio astronomica de usu globorum \& sphaerarum caelestium ac terrestrium (Amsterdam 1655) 112. The first (Dutch) edition of this book appeared in 1634. There are no notable textual differences between the various Dutch and Latin editions.

52. Blaeu, Institutio astronomica (ref. 51). On p. 112-116 Blaeu calculated the houses assuming that the earth is at rest, on p. 222-224 supposing it to be moving. The horoscope is drawn on p. 116. Cf. Adriaan Metius, De genuino usu utriusque globi tractatus (Franeker 1624) 93. The earlier edition Doctrinae sphericae lib. V (ref. 5), instead had the horoscope of Heinrich von Rantzau.

53. Fernand Hallyn, 'Un poème inédit de Philippe Lansbergen sur l'étoile nouvelle de 1604', Humanistica Lovaniensia. Journal of neo-Latin studies xlvi (1997) 258-265.

54. The only reference is in a private letter. For a translation, see Rienk Vermij, 'Johannes Phocylides Holwarda and the interpretation of new stars in the Dutch Republic', in: Patrick Boner ed., Change and continuity in early modern cosmology (Dordrecht etc. 2011) 136.

55. Lansbergen, Bedenckingen (ref. 48), 77. 
56. Mulerius, Almanach 1608 (ref. 40), [C4].

57. Mulerius, Institutionum astronomicarum (ref. 36), 20-21.

58. On the debate on comets in an academic context, cf. Van Miert, Humanism (ref. 29), 259-264.

59. Jacob Ravensberg, Encyclopedia mathematica (1642), 10. On Ravensberg: Vermij, Calvinist Copernicans (ref. 12), 123-126.

60. Johannes Phocylides Holwarda, Panselenos ekleiptikè diaugazousa (1640), 276: "quas ego sane odi pessime, tanquam vanissimas abominationes, \& sub maledictionis poenâ in sacris nobis interdictas." Idem, Epitome astronomiae reformatae generalis (Franeker 1654) 75-76: "Sanè nos tantum abest ut vanissimis illis nugivendulorum Calendariographorum praedictionibus patrocinemur, ut contra potius abominabiles eas \& coram Deo detestabiles Astrologorum prognoscis, toto animo execremur, \& Christianis sub divinae maledictionis poena prohibitas esse censeamus.” On Holwarda, see R.H. Vermij, 'Johannes Phocylides Holwarda' (ref. 54), $135-152$.

61. Descartes to Mersenne, 1640 Jan. 29. René Descartes, Oeuvres, Ch. Adam and P. Tannery ed., III (Paris 1899) 15.

62. Martinus Hortensius, Dissertatio de Mercurio in sole viso et Venus invisa (Leiden 1633) 67. On this book, see Albert Van Helden, Measuring the universe. Cosmic dimensions from Aristotarchus to Halley (Chicago and London 1985) 101-103. On Hortensius, see Van Miert, Humanism (ref. 28) 55-59, 250-254.

63. Holwarda became professor of philosophy, not of astronomy, but his professional identity is really that of an astronomer: he made observations, published astronomical tables, etc.

64. Johannes Murdison, Theses philosophicae de anatomia universae naturae, 1601 June 2, respondens: Richard Bland, th. 11, 13.

65. Gilbert Jachaeus, Disputationum physicarum septima de coelo, 1607 Dec. 22, Gosardus Dremmius resp., th. 6.

66. Hadrianus Smoutius resp., Positiones philosophicae, 1600 Dec. 9 (no praeses), th. 19.

67. Franco Burgersdijk, Disputationum physicarum septima, de coelo, 1627 June 16, Marcus Mamuchet resp., th. 19-22.

68. See the article on Kyper (by Han van Ruler) in W. van Bunge a.o. ed., Dictionary of seventeenth and eighteenth century Dutch philosophers (Bristol 2003) II, 581-583.

69. Albertus Kyper, Institutiones physicae (Leiden 1645-1646), liber IV, 81. The passages relevant to astrology are 76-85, 100-102.

70. Ibid., $81-82$.

71. Ibid., 82 .

72. Henricus Renerius, Disputationum physicarum tertia, De mundi et caelo. Utrecht 1635 June 10. (Ludovicus a Vosberghen resp.), thesis 26.

73. Ibid., thesis 39 .

74. On Beeckman, see K. van Berkel, Isaac Beeckman (ref. 3). See pp. 250-251 for his rejection of astrology.

75. Journal tenu par Isaac Beeckman de 1604 à 1634, C. de Waard ed. (4 vol., The Hague 19391953) I, 97 (1616), see also 99; III, 207-208.

76. Ibid., I, 110-111, 111-112.

77. Ibid., III, 34-35: "jae selfs diergelycke prognosticatie [te] doen verfoyende."

78. Ibid., III, 214-215: "datter niemant en is die min vertrouwt op voorsegghingen als ick doe, door de onwetentheyt der menschen."

79. Some academic disputations do mention the subject. Antonius Deusing, Disputationum physicarum quinta. Continens continuationem creationes. De operibus quarti diei (Harderwijk 1641 Febr. 25; Joh. Achterkerken resp.). Martin Schoock, an ally of Voetius, mentioned celestial influence in a disputation from 1648, but mainly to emphasize its limitations: Martin 
Schoock, Disputationun [sic] philosophicarum de convenientia orbis coelestis ac elementaris prima (Groningen 1648 June 21; Anthonius à Dorth resp.) th. 2-7. Johannes Klenckius, Disputationum physicarum prima, de physica natura (Amsterdam 1653 Jan. 15; Antonius Haselbroeck resp.) th. 24 mentions astrology along with cheiromancy and physiognomy. In the second disputation of the same series, De causa efficiente corporum naturalium (Amsterdam 1653 Jan. 27; Paulus Leupenius resp.) th. 22, Klenckius discussed and rejected the idea that fate was determined by the stars.

80. Cf. for somewhat similar arguments, Tayra M.C. Lanuza Navarro, 'Astrological predictions in seventeenth-century Spain', in: Víctor Navarro Brotóns and William Eamon ed., Más allá de la leyenda negra: España y la revolución cientifica. Beyond the black legend: Spain and the scientific revolution (Valencia 2007) 80-81; Whitfield, Astrology (ref. 9), 184.

81. Claudia Brosseder, Im Bann der Sterne. Caspar Peucer, Philipp Melanchthon und andere Wittenberger Astrologen (Berlin 2004).

82. Westman, Copernican question (ref. 6), passim. 